\title{
Gnathostomiasis: Report of a case and brief review
}

\author{
STAN HOUSTON MD DTM+H FRCPC
}

\begin{abstract}
S Houston. Gnathostomiasis: Report of a case and brief review. Can J Infect Dis 1994;5(3):125-129. Nematodes of the genus Gnathostoma can cause a spectrum of disease in humans. This includes a distinctive syndrome of intermittent migratory subcutaneous swellings, central nervous system involvement with high morbidity and mortality and occasionally, involvement of other organs. Gnathostomiasis is endemic in southern and eastern Asia, particularly Thailand, but has recently been reported from Ecuador and Mexico. Diagnosis is usually based on clinical, epidemiological and serological findings. A recent study suggests that treatment with albendazole is effective. This report describes a patient diagnosed in Canada in whom evidence of pericarditis was associated with gnathostomiasis and in whom treatment with albendazole appears to have been effective.
\end{abstract}

Key Words: Albendazole, Drug therapy, Eosinophilic meningitis, Gnathostoma spinigerum, Gnathostomiasis, Pericarditis

\section{La gnathostomiase : Étude de cas et revue brève}

RÉSUMÉ : Les nématodes du genre Gnathostoma peuvent causer de nombreuses affections chez l'humain notamment un syndrome distinctif de nodules sous-cutanés qui effectuent des migrations erratiques, et un envahissement du système nerveux central entraînant une mortalité et une morbidité élevées. À l'occasion, d'autres organes seront également touchés. La gnathostomiase est endémique dans le Sud-Est asiatique, surtout en Thaillande. Cependant, des cas ont été récemment signalés en Équateur et au Mexique. Le diagnostic repose habituellement sur les résultats sérologiques, épidémiologiques et cliniques. D’après une étude récente, l'albendazole serait efficace pour traiter cette affection. La présente étude décrit le cas d'un patient sur lequel un diagnostic de péricardite associée à la gnathostomiase a été posé au Canada et qui semble avoir répondu à un traitement avec de l'albendazole.

G NATHOSTOMA SPINIGERUM WAS FIRST IDENTIFIED IN THE gastric tumour of a tiger in 1836 (1). Human gnathostomiasis was first reported from Thailand in 1890 in a woman presenting with a breast mass (2). The disease is being recognized with increasing frequency due to better appreciation of the clinical features and improved diagnostic techniques. It is sufficiently com- mon in endemic regions that occasional cases can be expected in North America, yet North American physicians are often not familiar with the disorder. Two recent developments make awareness of this infection more important: the recognition of endemic foci in the western hemisphere and evidence that medical therapy is effective.

Division of Infectious Diseases, University of Alberta Hospitals, Edmonton, Alberta

Correspondence and reprints: Dr S Houston, Division of Infectious Diseases, 2E4.11 - Walter Mackenzie Centre, University of Alberta Hospitals, Edmonton, Alberta T6G 2B7

Received for publication March 10, 1993. Accepted August 26, 1993 
This report describes a patient whose gnathostomiasis was diagnosed in a very nontropical Canadian city and who had clinical evidence of pericardial involvement which has been reported only once previously.

\section{CASE PRESENTATION}

A 31-year-old woman of Thai origin was referred because of eosinophilia and recurrent superficial swellings.

She first noticed the swelling about six years previously and described almost identical recurrences approximately once a year since then. Each episode was characterized by the rapid appearance of a mildly painful swelling over the right lower forearm lasting about two weeks. Episodes were not accompanied by fever or other systemic symptoms nor by swelling or pruritis at any other site. She specifically denied any history of serious neurological disease or chest pain. She was entirely well between episodes. She had presented with similar symptoms to a physician in Canada two years previously. A peripheral eosinophilia was present and strongyloides larvae were found on stool examination at that time, but the eosinophilia resolved after treatment with thiabendazole. Her past history was otherwise negative.

The patient had spent most of her life in a small village in northern Thailand. Although now married to a Canadian, she continues to spend about six months each year in Thailand. She admitted eating a variety of local foods in Thailand including uncooked fish.

On examination she was afebrile and looked well. There was a subcutaneous swelling 4 to $5 \mathrm{~cm}$ in diameter with poorly defined margins over the distal right forearm. It was mildly tender but neither warm nor red. The only other abnormality on physical examination was a loud pericardial rub. This was documented by two physicians at the first visit and was noted at a subsequent visit two weeks later in spite of having been found to be absent on one examination in the interval. The cardiovascular system was otherwise completely normal with no evidence of tamponade.

The absolute eosinophil count was $5.9 \times 10^{9} / \mathrm{L}$. Chest $\mathrm{x}$-ray and electrocardiogram were normal; echocardiography revealed a trace of pericardial fluid. Western blot examination of serum using a somatic extract of the third stage larva of Gnathostoma spinigerum (3) supported the clinical diagnosis of gnathostomiasis.

The swelling resolved completely without specific treatment. Albendazole $400 \mathrm{mg}$ twice daily was given by mouth for 14 days starting several weeks after resolution of the swelling. No adverse effects were associated with the treatment. The pericardial rub was absent on each of several examinations performed more than two weeks after initial presentation. No recurrent swelling had been noted when the patient was contacted 30 months after completion of therapy and the absolute eosinophil count at 21 months was $0.2 \times 10^{9} / \mathrm{L}$.

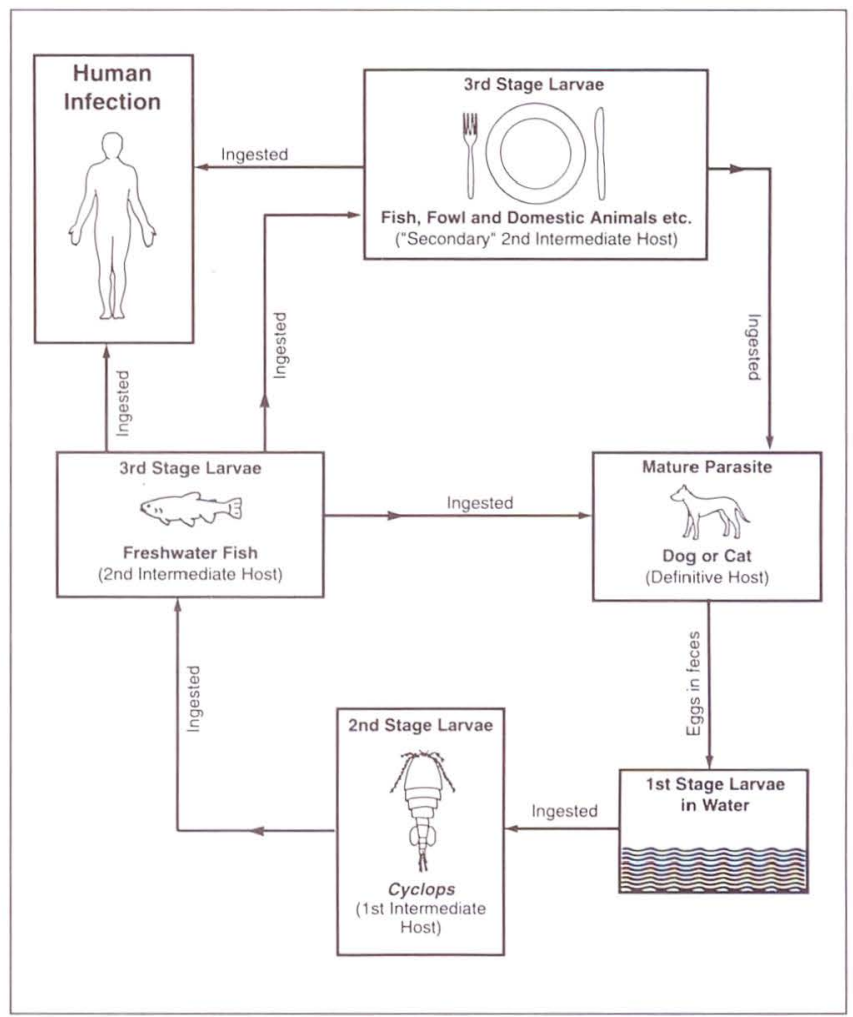

Figure 1) Life cycle of Gnathostoma spinigerum showing usual routes of human infection

\section{DISCUSSION}

Human gnathostomiasis is usually caused by the nematode $G$ spinigerum. Cases of human disease due to Gnathostoma hispidum (4), Gnathostoma nipponicum (5) and Gnathostoma doloresi (6) have been described.

Life cycle (Figure 1): First-stage larvae in water are ingested by a tiny crustacean, cyclops. Second-stage larvae in infected cyclops are in turn ingested by a second intermediate host, frequently one of several species of fresh water fish. The parasite penetrates the gastric wall and the third-stage larva encysts in the muscle of the second intermediate host. 'Secondary' infection with third-stage larvae, of another second intermediate host, can occur if it ingests the 'primary' second intermediate host. This has been demonstrated experimentally in at least 33 animals including crustaceans, fish, amphibians, reptiles, birds and mammals, and appears to occur commonly in nature (7). The infection is productive only in the definitive hosts - dogs, cats and some wild animals - where larvae mature in the wall of the stomach, mate there and release eggs into the feces. The eggs hatch in water producing firststage larvae.

The main source of human infection is thought to be ingestion of inadequately cooked flesh of either the 'primary' or 'secondary' second intermediate hosts harbouring third-stage larvae. Fresh water fish and domestic poultry may be the most important sources (8). Based on animal models, it is thought that ingestion of 
water containing infected cyclops may be an occasional mechanism for human infection (9). Experimentally, the parasite can penetrate the intact skin of cats, indicating that handling the flesh of infected fish could also be a source of human infection (10). Three cases of apparent perinatal transmission have been reported $(11,12)$. Human infection involves third-stage larvae of either sex and of varying degrees of maturity, ranging from 2.2 to $16.25 \mathrm{~mm}$ in length (11).

Geographic distribution: Most cases of human gnathostomiasis have been reported from Asia, particularly Thailand but including China, Japan and several countries of southeast Asia from Bangladesh to the Philippines. One case was reported in a woman who had lived only in Europe and Israel (13). Recently there has been a number of reports of human gnathostomiasis from Latin America (14-16) and infested fresh water fish have been documented there (17).

Clinical features: It is thought that symptoms and organ damage in gnathostomiasis are due to mechanical tissue injury produced by this macroscopic nematode in its migrations.

The incubation period between ingestion of gnathostoma larvae and the first development of cutaneous symptoms is three to four weeks (7). Abdominal pain and vomiting occurred within 24 to $48 \mathrm{~h}$, followed by pulmonary, then cutaneous symptoms in a common source outbreak involving nine individuals who consumed raw fish at a party (18).

The clinical features of reported cases of gnathostomiasis are documented in two comprehensive reviews $(9,19)$. The most common presentation is that of recurrent subcutaneous swellings which are usually painless but sometimes associated with pain sufficient to result in confusion with bacterial cellulitis. These swellings reflect the migration of the parasite. They may last one to two weeks and recur at intervals of weeks to months at the same or different sites. Systemic symptoms are not usually noted. A peripheral eosinophilia is usual but not invariable. A superficial creeping eruption has also been described (20). There is a tendency for recurrences to become less frequent and less severe over time but they may persist for over 10 years indicating that the parasite may live that long in the human host. A syndrome of migratory subcutaneous nodules may also be seen in paragonimus infections (62).

The most serious manifestation of gnathostomiasis is central nervous system (CNS) involvement, first proven only in 1967 (21) although it had been previously suspected $(22,23)$. Recognized presentations include encephalitis, painful radiculitis, myelitis, cranial nerve palsies, subarachnoid hemorrhage (24) and eosinophilic meningitis or combinations of these. Gnathostoma, unlike angiostrongylus, does not seem to be neurotropic but to involve the cNs only by chance. Brain involvement and subarachnoid hemorrhage have also been described in infections with Paragonimus westermani var szechuanensis (62). CNS gnathostomiasis may occur in any age group. Only 7\% of 162 patients in one report had a history of intermittent migratory cutaneous swellings while $4 \%$ had unilateral eyelid swelling (25).

Peripheral eosinophilia is usual in cNS gnathostomiasis - an eosinophilia of greater than 10\% was found in $57 \%$ in one series (25). Cerebrospinal fluid (CSF) pleocytosis with at least $10 \%$ eosinophils is present at some point in the course of nearly all patients with CNS gnathostomiasis $(25,26)$. The other important cause of eosinophilic meningitis, Angiostrongylus cantonensis, is also endemic in parts of southeast Asia but the clinical syndrome is usually one of meningeal involvement only and is self-limiting (27). Among 162 patients with CNS gnathostomiasis, bloody or xanthochromic CSF was found in $64 \%$, csF pressure was elevated in more than half, cSF protein exceeded $50 \mathrm{mg} / 100 \mathrm{~mL}$ in $72 \%$ but CSF glucose was depressed in only 10\% (25).

Case fatality was at least $12 \%$ among 162 patients with probable cNs gnathostomiasis in the largest series (25). The authors believed the true case fatality rate was considerably higher since 38 patients were taken home unimproved, many critically ill. Sixty-five per cent were considered 'improved', many with persisting neurological deficits. Autopsies of patients with CNS gnathostomiasis have revealed grossly visible worm tracks with accompanying necrosis and hemorrhage in the brain or spinal cord (28).

Gnathostomiasis has also been reported to involve the eye $(13,29-41)$, the urinary $(42,43)$ and genital tracts $(44,45)$, the ear $(46,47)$, the abdomen $(48,49)$, the breast (2,50), and the lung or pleura (51-55). Ocular involvement seems to be the least uncommon of these; even with prompt surgical removal of the worm, permanent injury is common.

There is one report in the literature of a patient with a pericardial effusion, documented by echocardiogram, associated with gnathostomiasis (56). The patient, of Nepalese origin, also had a pleural effusion, peripheral eosinophilia and intermittent migratory swellings over the chest wall from one of which a gnathostome was removed. Following removal of the worm (and treatment with diethylcarbamazine) the patient experienced prompt clinical and radiological improvement without relapse.

Diagnosis: The diagnosis of gnathostomiasis is usually made in the presence of a distinctive clinical syndrome, most often intermittent migratory swellings or compatible cNS disease, in a person from an endemic area. Retrieval and identification of the worm confirm the diagnosis with certainty when this is possible. Even when the worm is missed, histology of the panniculitis lesions is said by one author to be characteristic (14). The presence of a marked peripheral blood eosinophilia is typical but not invariable (57). Skin testing for gnathostomiasis has been used, but recent develop- 
ments in serological testing appear to be very promising (3.58).

Treatment: Until recently the only treatment known to be effective was removal of the worm. Corticosteroids may speed resolution of cutaneous swellings (56) but have not been proven to have any benefit in the most serious form of the disease - in the CNS (25). Ivermectin and albendazole appear to have a therapeutic effect in animal models $(59,60)$. One recent report describes the elimination of episodes of intermittent migratory swelling at six months follow-up in 89 of 100 patients treated orally with either $400 \mathrm{mg}$ daily or $400 \mathrm{mg}$ bid of albendazole for 21 days (61), while recurrences were noted in all 12 placebo recipients. Eosinophilia resolved in more than $90 \%$ of those treated but in only one of 12 placebo recipients, and serological titres declined in the treat-

ACKNOWLEDGEMENTS: The author gratefully acknowledges the assistance of Dr Wanpen Chaicumpa, Mahidol University, Thailand, who performed the serological testing on this patient. and SmithKline Beecham for providing albendazole.

\section{REFERENCES}

1. Owen R. Anatomical descriptions of two species of entozoa from the stomach of a tiger (Filis tigris), one of which forms a new genus of Nematoidea, Gnathostoma. Proc Zool Soc Lond 1836; $47: 123$.

2. Levinson GCM. Om en ny Rundom hos mennesket Cheiracanthus siamensis n sp. Kjhobenhovn: Naturhistoriske Forening, 1889:323-6.

3. Tapchaisri P. Nopparatana C, Chaicumpa W, Setasuban P. Specific antigen of Gnathostoma spinigerum for immunodiagnosis of human gnathostomiasis. Int $\mathrm{J}$ Parasitol 1991:21:315-9.

4. Taniguchi Y, Katsuhiko A, Isoda K-I, Shimizu M, Sonobe K. Human gnathostomiasis: successful removal of Gnathostoma hispidum. Int J Dermatol 1992:31:175-7.

5. Ando K, Tanaka H, Taniguchi Y, Shimizu M, Kondo K. Two human cases of gnathostomiasis and discovery of a second intermediate host of Gnathostoma nipponicum in Japan. J Parasitol 1988:74:623-7.

6. Ogata K, Imai J, Nawa Y. Three confirmed and five suspected human cases of Gnathostoma doloresi infection found in Miyazaki Prefecture, Kyushu. Jpn J Parasitol 1988;37:358-64.

7. Miyazaki I. On the genus Gnathostoma and human gnathostomiasis, with special reference to Japan. Exp Parasitol 1960;9:338-70.

8. Daengsvang $\mathrm{S}$, Thienprasitthi $\mathrm{P}$, Chomcherngpat $\mathrm{P}$, Further investigations on natural and experimental hosts of larvae of Gnathostoma spinigerum in Thailand. Am J Trop Med Hyg 1966; 15:727-9.

9. Daengsvang S. A monograph on the genus Gnathostoma and gnathostomiasis in Thailand. Tokyo: Southeast Asian Medical Information Center, 1980.

10. Daengsvang S, Sermswatsri B, Youngyi, et al. Penetration of the skin by Gnathostoma spinigerum larvae. Ann Trop Med Parasitol 1970:64:399-402.

11. Radomyos P. Daengsvang S. A brief report on Gnathostoma spinigerum specimens obtained from human cases. Southeast Asian J Trop Med Public Health 1987;18:215-7.

12. Daengsvang $\mathrm{S}$. Contributions to natural sources and ment but not the placebo group. Interestingly, treatment appeared to provoke migration of the larvae to the skin where 22 were removed from 21 patients. It is to be hoped that longer follow-up and further experience will confirm these very encouraging results. There are no reports of albendazole treatment of cNS disease.

In the presented patient the typical history and appearance of intermittent migratory swellings, the epidemiological history, and the positive serological test clearly indicate a diagnosis of gnathostomiasis. A pericardial rub is an objective clinical finding which is rarely if ever 'incidental'. The striking temporal association of a pericardial rub with an episode of intermittent migratory swelling, and the absence of an alternative cause, strongly suggest that it was related to gnathostomiasis.

methods of transmission of Gnathostoma spinigerum in Thailand. Southeast Asian J Trop Med Public Health 1976;7:95-101.

13. Witenberg G, Jacoby J, Stechelmacher S. A case of ocular gnathostomiasis. Ophthalmologica 1950;119:114-22.

14. Ollague W, Ollague J, Guevara de Veliz A, Penaherrera S. Human gnathostomiasis in Ecuador (nodular migratory eosinophilic panniculitis) first finding of the parasite in South America. Int J Dermatol 1984;23:647-51.

15. Martinez-Cruz JM, Bravo-Zamudio R, Aranda-Patraca A, Martinez-Maranon R. La Gnatostomiasis en Mexico. Salud Publica de Mexico 1989;31:541-9.

16. Kaminsky CA, De Kaminsky AR, Constantini SE, Abulafia J. Paniculitis nodular migratoria eosinofilica (gnathostomiasis humana). Med Cutan Ibero Lat Am 1989;17:158-62.

17. Ollague LW, Gomez LE, Briones IM. Infeccion natural de peces de agua dulce con el tercer estado larvario de Gnathostoma spinigerum y su dinamica de transmision al hombre. Med Cutan Ibero Lat Am 1988;16:291-4.

18. Migasena S, Pitisuttithum P, Desakorn V. Gnathostoma larva migrans among guests of a New Year party. Southeast Asian J Trop Med Public Health 1991:22(Suppl):225-7.

19. Rusnak JM, Lucey DR. Clinical gnathostomiasis: case report and review of the English-language literature. Clin Infect Dis 1993; 16:33-50.

20. Pinkus H, Fan J, Degiusti D. Creeping eruption due to Gnathostoma spinigerum in a Taiwanese patient. Int $J$ Dermatol 1981:20:46-9.

21. Chitanondh H, Rosen L. Fatal eosinophilic encephalomyelitis caused by the nematode Gnathostoma spinigerum. Am J Trop Med Hyg 1967;16:638-45.

22. Bodhidat $\mathrm{P}$, Punyagupta $\mathrm{S}$. Intracranial gnathostomiasis (A case report). Royal Thai Med J 1956:9:278.

23. Kishida S. Sakagami H. A case of gnathostomiasis accompanied with aphasia. J Kyoto Prefect M Univ 1961;69:1149-50.

24. Visudhiphan P, Chiemchanya S, Somburanasin R, Dheandhanoo D. Causes of spontaneous subarachnoid hemorrhage in Thai infants and children. J Neurosurg 1980;53:185-7.

25. Punyagupta S, Bunnag T, Juttijudata P. Eosinophilic meningitis in Thailand. J Neurol Sci 1990;96:241-56.

26. Schmutzhard E, Boongird P, Vejjajiva A. Eosinophilic meningitis and radiculomyelitis in Thailand, caused by CNS invasion of Gnathostoma spinigerum and Angiostrongylus cantonensis. J Neurol Neurosurg 
Psychiatry 1988;51:80-7.

27. Punyagupta S, Juttijudata P, Bunnag T. Eosinophilic meningitis in Thailand. Clinical studies of 484 typical cases probably caused by Angiostrongylus cantonensis. Am J Trop Med Hyg 1975;24:921-31.

28. Bunnag T, Comer DS. Punyagupta S. Eosinophilic myeloencephalitis caused by Gnathostoma spinigerum neuropathology of nine cases. J Neurol Sci 1970;10:419-34.

29. Tudor RC, Blair E. Gnathostoma spinigerum: an unusual cause of ocular nematodiasis in the western hemisphere. Am J Ophthalmol 1971;72:185-90.

30. Sirisamban BS. Report of an eye infection with Tua Chid (G spinigerum) J Med Assoc Thai 1941:24:401.

31. Teekhasaenee C, Ritch R, Kanchanaranya C. Ocular parasitic infection in Thailand. Rev Infect Dis 1986;8:350-6.

32. Kittiponghansa S, Prabriputaloong A, Pariyanonda S, Ritch R. Intracameral gnathostomiasis: a cause of anterior uveitis and secondary glaucoma. $\mathrm{Br} \mathrm{J}$ Ophthalmol 1987:618-22.

33. Bathrick ME, Mango CA, Mueller JF. Intraocular gnathostomiasis. Ophthalmology 1981;88:1293-5.

34. Chang E. Uveitis of a Cantonese caused by $G$ spinigerum (Owen 1836): Report of a case. Chin Med J 1949;67:166.

35. Chen HT. A human ocular infection by Gnathostoma in China. J Parasitol 1959;35:431

36. Gyi K. Intra-ocular gnathostomiasis. $\mathrm{Br} \mathrm{J}$ Ophthalmol 1960:44:42-5.

37. Khin T. Intra-ocular gnathostomiasis. Br J Ophthalmol 1968;52:57-60.

38. Mukerji AK, Bhaduri NV. Gnathostome infection of the eye. Indian Med Gaz 1945:12:126.

39. Sen K, Ghose N. Ocular gnathostomiasis. Br J Ophthalmol 1945;618-26.

40. Choudhury AR. Ocular gnathostomiasis. Am J Ophthalmol 1970;70:276-8.

41. Seal GN, Gupta AK, Das MK. Intra-ocular gnathostomiasis. J All-India Ophthalmol Soc 1969;17:109.

42. Nitidandhaprabhas P, Sirikarna A, Harnsomburana K, Thepsitthar P. Human urinary gnathostomiasis: a case report from Thailand. Am J Trop Med Hyg 1975;24:49-51.

43. Horohoe JJ, Ritterson AL, Chessin LN. Urinary gnathostomiasis. JAMA 1984;251:255-6.

44. Nitidandhaprabhas P. Sirimachan S, Charnvises K. A case of penile gnathostomiasis in Thailand. Am J Trop Med Hyg 1978;27:1282-3.

45. Hadidjaja P, Margono SS, Moeloek FA. Gnathostoma spinigerum from the cervix of a woman in Jakarta. Am J Trop Med Hyg 1979;28:161-2.

46. Cutchavaree A, Supiyaphun P, Sitthichareonchai P. Suphanakorn S. A case of aural gnathostomiasis. Auris Nasus Larynx 1984:12:163-7.
47. Prasansuk S. Hinchcliffe R. Gnathostomiasis a case of otological interest. Arch Otolaryngol 1975;101:254-8.

48. Sirikulchayanonta V, Chongchitnant N. Gnathostomiasis, a possible etiologic agent of eosinophilic granuloma of the gastrointestinal tract. Am J Trop Med Hyg 1979;28:42-4.

49. Daengsvang S. An abdominal tumour caused by Gnathostoma spinigerum (Owen 1836). Indian Med Gaz 1939;74:399.

50. Tesjaroen S, Wongkongsawat T, Parichatikanond P. A breast mass caused by gnathostomiasis: brief report of a case. Southeast Asian J Trop Med Public Health 1990:21:151-3.

51. Nitidandhaprabhas P, Hanchansin S, Vongsloesvidhya Y. A case of expectoration of Gnathostoma spinigerum in Thailand. Am J Trop Med Hyg 1975;24:547-8.

52. Fontan PR, Beauchamp F, Beaver PC. Sur quelques helminthiases humaine nouvelles au Laos. I. Nematodes. Bull Soc Pathol Exot 1975:68:557-66.

53. Prijyanonda B, Pradatsundarasar A, Viranuvatti V. Pulmonary gnathostomiasis: a case report. Ann Trop Med Parasitol 1955:49:121-2.

54. Miyachi S, Hisatomi T, Ito F, et al. A case of PIE (pulmonary infiltration with eosinophilia syndrome) caused by Gnathostoma spinigerum - a case confirmed by skin biopsy. Nippon Kyobu Shikkan Gakkai Zasshi 1981;19:409-13.

55. Bovornkitti S, Tandhanand S. A case of spontaneous pneumothorax complicating gnathostomiasis. Dis Chest 1959:35:328-31.

56. Nagler A, Pollack S, Hassoun G, Kerner H, Barzilai D. Lengy J. Human pleuropulmonary gnathostomiasis: a case report from Israel. Israel J Med Sci 1983;19:834-7.

57. Feinstein RJ, Rodriguez-Valdes J. Gnathostomiasis, or larva migrans profundus. J Acad Dermatol 1984; 11:738-40.

58. Nopparatana C, Setasuban P, Chaicumpa W, Tapchaisri P. Purification of Gnathostoma spinigerum specific antigen and immunodiagnosis of human gnathostomiasis. Int $\mathrm{J}$ Parasitol 1991;21:677-87.

59. Anantaphruti MT, Nuamtanong S. Waikagul J. Effect of ivermectin on experimental gnathostomiasis in rabbits. Trop Med Parasitol 1991;43:65-7.

60. Maleewong W, Loahabhan P, Wongkham C, Intapan P, Morakote N, Khamboonruang C. Effects of albendazole on Gnathostoma spinigerum in mice. J Parasitol 1992:78:125-6.

61. Kraivichian P, Kulkumthorn M, Yingyourd P, Akarabovorn P, Paireepai CC. Albendazole for the treatment of human gnathostomiasis. Trans R Soc Trop Med Hyg 1992;86:418-21.

62. Goldsmith R, Bunnag D, Bunnag T. Lung fluke infections: Paragonimus. In: Strickland GT, ed. Hunter's Tropical Medicine, 7th edn. Philadelphia: WB Saunders, 1991:827-31. 


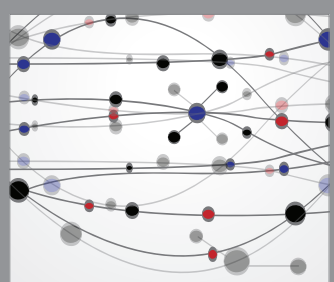

The Scientific World Journal
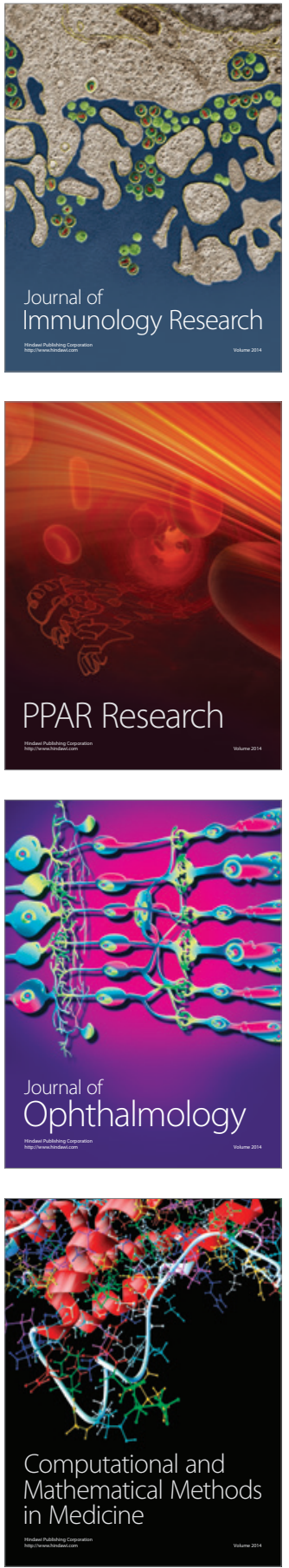

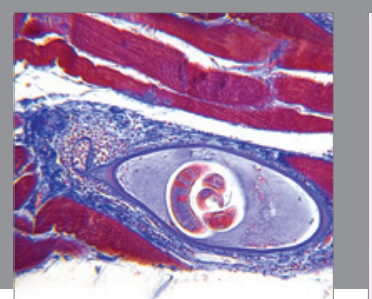

Gastroenterology Research and Practice

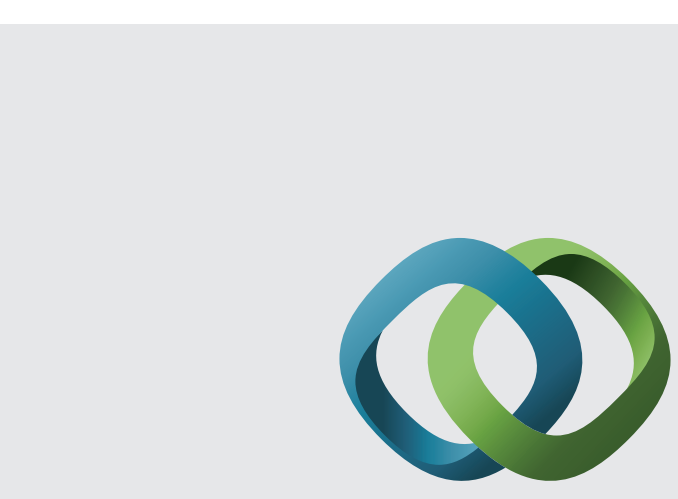

\section{Hindawi}

Submit your manuscripts at

http://www.hindawi.com
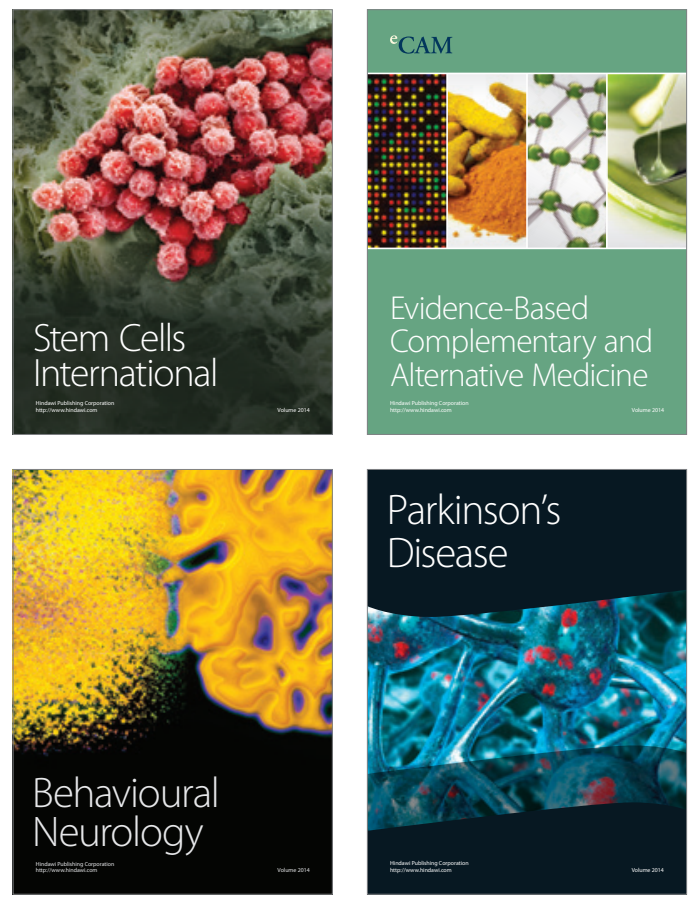
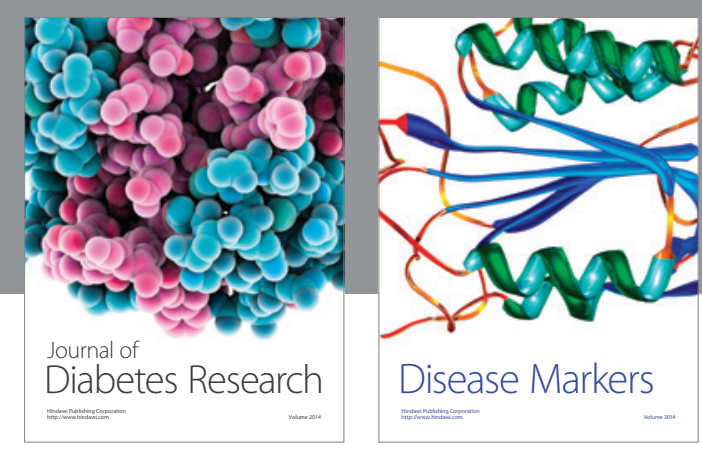

Disease Markers
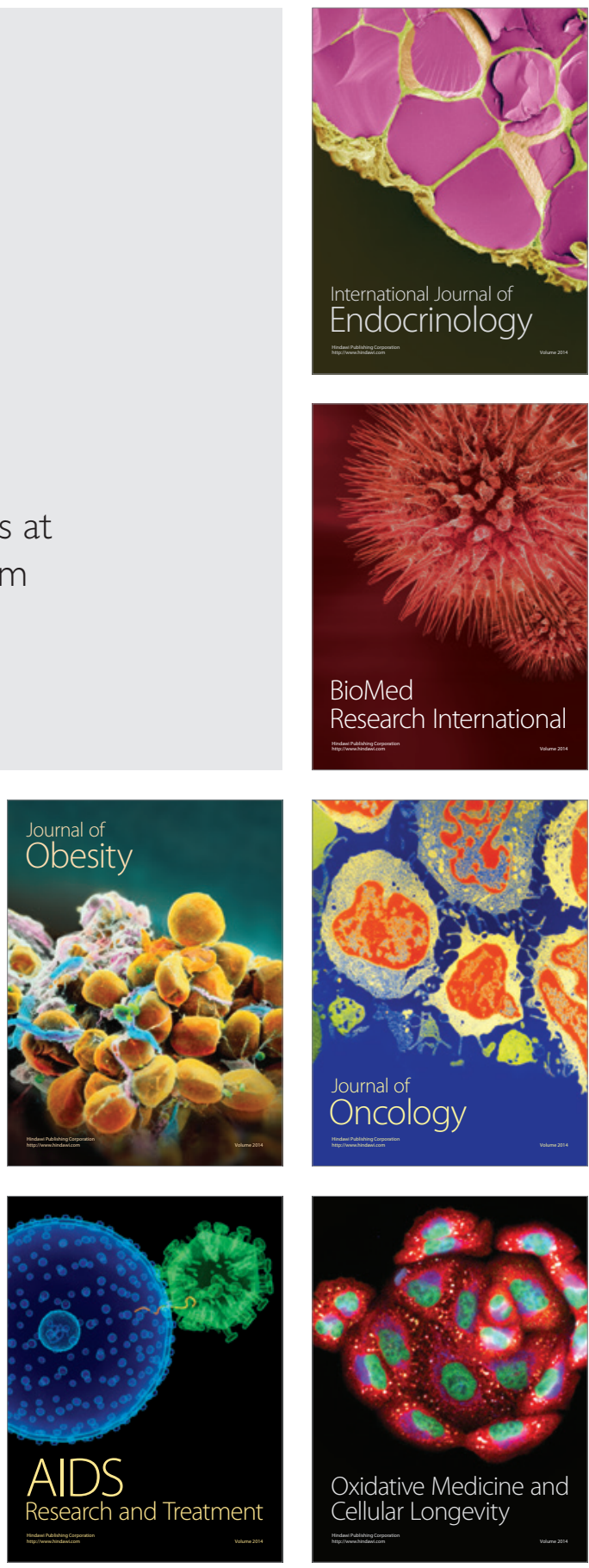